\section{Imanishi's influence on evolution theory in Japan}

SIR-My Commentary ${ }^{1}$ on Imanishi's theory of evolution and the Japanese dimension evoked a gratifying range of responses $^{2-9}$. Several correspondents ${ }^{3,4}$ complained about my article being more sociological than scientific. This is indeed the case as my aim was primarily to describe Imanishi's theory and set it in its social context - there is little to be said about its scientific content.

Whereas Nakahara et al. ${ }^{5}$ claimed that I had rejected Imanishi's theory without fully understanding it, the actual wording of my summary was checked by Imanishi himself who stated "I was very impressed that you have got the ideas very precisely in spite of the language difficulty".

Some of the Western correspondents, such as Sinclair ${ }^{3}$, obviously found Imanishi's theory so unusual that they could not believe what I had carefully written. Sinclair states "Imanishi no doubt would not deny that interspecific competition exists", yet that is precisely what Imanishi contends; such denial is the very essence of his theory and it is this which makes it unique. I certainly did not confuse the roles of intraspecific and interspecific competition. Needless to say, I agree that natural selection and the entire edifice of Darwinism requires intraspecific competition. Similarly, I agree with Millar et al. ${ }^{4}$ that aspects of Imanishi's theory are not unique, such as the denial of the importance of intraspecific competition and his assertion "that the unit for explaining evolution is not the individual but the species". Many of Imanishi's ideas are mirrored in the separate and joint writings of Eldredge and Gould ${ }^{10-13}$. Indeed, Imanishi has intimated his sympathy with much of Gould's writings, and is especially sympathetic to the notion of sudden jumps in evolution, and states "evolution is change occurring when it is time to change".

It is perhaps significant that these selfsame ideas are to be found in the writings of Lysenko ${ }^{14}$ (with his own emphasis):

\footnotetext{
"No continuous, unbroken series of forms between species - different qualitatively definite states of living matter - have been found. This is so not because the intermediate forms in a continuous range have died out as a result of mutual competition, but because there is no such continuity in nature, nor can there be. A species is a distinct, qualitatively definite state of living matter. We must realize that speciation is a transition - in the course of the historical process - from quantitative to qualitative variations. Such a leap is prepared by the vital activity of organic forms themselves, as the result of quantitative accumulation of responses to the action of definite conditions of life, and that is something that can definitely be studied and directed. The conversion of one species into another takes place by a leap.".
}

Interestingly, Japan is one of the few places where Lysenko is still taken seriously. The Japanese Society for Michurin Biology was set up in 1954, the Japanese Journal of Michurin Biology was launched in 1965 and still continues in the 1980s. There is clearly a sympathetic response to these ideas in Japan.

My brief discussion on the scientific basis of Imanishi's concepts of protoidentity and habitat segregation or life style partitioning, which I claimed had been effectively refuted, was challenged by Sibatani ${ }^{2}$ and Millar et al. ${ }^{4}$. The points they raised have been adequately dealt with by Rossiter ${ }^{6}$. I agree that habitat segregation is a real phenomenon, as Nakahara et al. ${ }^{5}$ insist, but it is not as they or Imanish suppose antithetical to natural selection. The late Kani and Imanishi's close colleague Morisita ${ }^{15}$ recognized the importance of interspecific competition. There is no conflict regarding observations of the phenomena. It is in the explanations proposed to account for them that disagreements arise. Hence I agree completely with Sakura et al. ${ }^{8}$ that "Imanishi's description of phenomena is not incompatible with Darwinian theory which deals with mechanisms of evolution".

Finally, I was pleased to read Sibitani's ${ }^{2}$ comments on "Japanese ethnocentric excesses" as well as the letter from the primatologists in Kyoto who say that although they "are still hampered by the influence of Imanishiism, we criticize his theory and try to eliminate its negative influence"8. This contrasts with Asquith" who challenged me on my general comments on the average intelligent layman's understanding of evolution, which I do not retract.

Darwin's work was indeed introduced into Japan in the last century and in fact social darwinism was one of the cornerstones of the social policy of the rigid authoritarianism of the Meiji restoration. It is against this particular background that the importance of Imanishi's oppostion to Darwinism must be viewed.

Imanishi is still a national hero, as he was in the 1930s. The popular press abounds with interviews and articles by and about him. Typical is the article in the English language magazine Look Japan (10 January, 1980) "Kinji Imanishi, Japanese Theorist - as compared to Darwin", in which the three great thinkers of modern times are seen as Darwin, Marx and Imanishi. The interview with Imanishi in the July 1984 issue of Omni (Japanese edition only) gives a very clear idea of the high esteem in which he is held.

Asquith ${ }^{9}$ confirms my critique of Japanese scientists. According to her "the majority of Japanese scientists simply disagree with Imanishi's popularizations and find his views obscure and untestable. Their silence is hardly surprising". My account was an attempt to draw attention to Imanishi's theories and to set them in their context, and if possible to provoke the Japanese scientific community into some kind of response. Sibatani's ${ }^{16}$ initial aim was to bring Imanishi's ideas to the attention of Western scientists. I was the first to respond. I set out in my book ${ }^{17}$ to bring to the attention of Japanese scientists the considered opinion of an individual Western scientist on the theories of Imanishi. I believe that both Sibatani and I have succeeded in our avowed intentions. BEVERLY HALSTEAD
Departments of Geology and Zoology,
University of Reading, RG6 $2 A B, U K$
1. Halstead, B. Nature 317, 587-589(1985).
2. Sibatani, A. Nature 320, 492(1986).
3. Sinclair, M. Nature 320, 540 (1986).
4. Millar, C.D., Phillips, N.R. \& Lambert, D.M. Nature 321,
475 (1986).
5. Nakahara, J., Sagawa, T. \& Fuke T. Nature 321, 475 (1986).

6. Rossiter, A. Nature 322, 315-316 (1986)

7. Iles, T.D. Nature 323, 576 (1986).

8. Sakura, O., Sawaguchi, T., Kudo, H.I. \& Yoshibubo, S. Nature 323, 586 (1986)

9. Asquith, P.J. Nature 323, 675 (1986)

10. Eldredge, N. \& Gould, S.J. in Models in Paleobiology (ed. Schopf, T.J.M.) $82-115$ (Freeman, San Francisco, 1972).

11. Gould, S. J. \& Eldredge, N. Paleobiology 3, 115-151 (1977).

12. Gould S.J. Science 216, 380-387 (1982).

13. Eldredge, N. Times Frames: the Rethinking of Darwinian Evolution and the Theory of Punctuated Equlibria (Heinemann, London, 1985); Unfinished Synthesis: Biological Hierarchies and Modern Evolutionary Thought (Oxford University Press, 1985).

14. Lysenko, T.D. Agrobiology (Foreign Languages Publishing House, Moscow, 1954).

15. Morisita, M. in Halstead, L.B. Kinji Imanishi - the View from the Mountain Top: a Critique of Imanishi's Theory of Evolution (Tsukiji Shokan, Tokyo, in the press). (In Japanese).

16. Sibatani, A. J. Social Biol. Struct. 6, 335-343 (1983).

17. Halstead, L.B. Kinji Imanishi - the View from the Moun tain Top: a Critique of Imanishi's Theory of Evolution (Tsukiji Shokan, Tokyo, in the press). (In Japanese).

This correspondence is now closed Editor, Nature.

\section{Macrophage regulation of vitamin $D_{3}$ metabolites}

SIR-In his provocative News and Views summary ${ }^{1}$ of some features of the vitamin D system, Ian Dickson discusses the formation of the active 1,25-dihydroxyvitamin $\mathrm{D}_{3}$ metabolite from 25 -hydroxyvitamin $\mathrm{D}_{3}$ by the enzyme 1-hydroxylase in the kidney. He also refers briefly to the existence of receptors for this metabolite on macrophages and in the thymus. The considerable importance of the latter observations is more obvious when one realises that macrophages can also express the 1-hydroxylase, which had been thought to occur only in the kidney. Moreover, this activity is enhanced dramatically when macrophages are exposed to gamma interferon ${ }^{2-4}$.

Thus the 1,25-dihydroxy metabolite formed by the macrophages can have an autocrine effect on these cells. For instance, in the system we have studied it increases the ability of cultured human monocytes to inhibit the in vitro growth of 